\title{
Az új Országos Célforgalmi Mátrixok (OCM- 2016) mint a közlekedéstervezés alapkövei
}

A célforgalmi mátrixok kidolgozásának hat évtizedes történetében jelentős változást hozott a 2016-2017-ben elkészült hetedik generáció. Az egyre gyorsuló technológiai fejlődés következtében a korábbinál jelentősebb méreteket öltött az amúgy mindig jelenlevő módszertani megújulás, a feladat ezúttal kiterjedt a közlekedés minden alágazatára, továbbá elvárás volt az előretekintés és a TEN-T szakaszokra összpontosító forgalmi elemzés. A cikk a munka egészébe nyújt betekintést, meghagyva a szakmai részleteket a jelen lapszám többi, szintén ezzel a projekttel foglalkozó írásainak.

DOI 10.24228/KTSZ.2017.5.1

\section{Albert Gábor}

e-mail: albert.gabor@kti.hu

\section{VISSZATEKINTÉS}

A forgalmi adatok gyüjtésének igénye ott merült fel először, ahol a pálya fenntartását tervezett módon kívánták megoldani. Magyarországon ilyen „pályák” az állami és országos utak voltak, a 19. század második feléig első sorban a Dunántúlon, a Felvidéken és Erdélyben, ahol a terület kevésbé volt árvízveszélyes és rendelkezésre állt a megfelelő kőanyag [1].

Az első hazai átfogó, az állami utakra kiterjedő forgalomszámlálás 1869-ben kezdődött, s hét éven át húzódott. A számlálás egysége az igavonó állatok száma volt, ami arányban állt a szállított áru tömegével. A számlálás szükségességét Hieronymi Károly vetette fel, olyan útfinanszírozási rendszert javasolva, ahol a forráselosztás arányos a leromlással, azaz a forgalom nagyságával.

Habár a forgalomszámlálás rendszere egyre kifinomultabbá vált, bizonyos feladatok megoldásához nem szolgáltatott elegendő információt. Az 1920-as évektől kezdve az Egyesült Államokban egyre gyakrabban egészítették ki a forgalomszámlást célforgalmi felméréssel, amit megállításos kikérdezéssel vagy utóbb visszajuttatott önkitöltős kérdőívvel végeztek. Ezek célja általában helyi vagy regionális fejlesztések optimális megoldásának, jellemzően hidak legkedvezőbb helyének megkeresése volt. Az első kiterjedt célforgalmi felvétel 1923-ban készült Tennessee államban. Ez és az ezt követő felmérések jellemzően városokra és környékükre terjedtek ki, ahol már nehézségeket okozott a forgalom nagysága.

Az első jelentős külterületi célforgalmi felmérést 1947-ben Havre kisváros (Montana) térségében végezték egy elkerülő út legkedvezőbb nyomvonalának meghatározásához. Ekkor már egy évtizede alkalmazták az eljárást úttervezési feladatokhoz városi környezetben [2].

Mindezek tükrében nem lehet túlbecsülni, hogy 1956-ban - 11 évvel a háború befejezését követően - Magyarországon megszervezték és végrehajtották a világ első országos célforgalmi adatfelvételét, egybekötve Európa első, a magyar fejlesztésü 
sampling ${ }^{1}$ módszerrel végzett keresztmetszeti forgalomszámlálásával. A kedvező tapasztalatok birtokában született döntés arról, hogy a felmérést viszonylag rövid időn belül, 1963-ban meg kell ismételni, a korábbinál nagyobb részletezettséggel. A törekvés érthető, tekintettel arra, hogy csak a célforgalmi vizsgálatok mutatják meg, hogy a közlekedési tér egyes pontjai, illetve térségei között mekkora a forgalmi igény.

A későbbiekben is rendszeresen, összességében mintegy tízévenként bonyolítottak le (a szakzsargonban OCF-ként említett) országos célforgalmi felméréseket, amelyek módszertani sajátosságaival a szerző korábban részletesebben is foglalkozott [3]. Ezeket egészen 1996-ig az jellemezte, hogy

- kizárólag a közúti közlekedésre terjedtek ki, - a személy- és tehergépkocsik adatait azonos alapelveken nyugvó, bár a jármúkategória sajátosságaihoz igazított módszerrel gyüjtötték,

- a felmérés területi modellje egyre részletesebbé vált, valamint

- az előző felmérések tapasztalatainak birtokában és a technológiai fejlődés által nyújtott új lehetőségeket keresve a szakemberek minden alkalommal részben vagy egészben új módszert alkalmaztak.

A 2007-2008-as adatfelvétel több jelentős változást hozott. A személygépkocsi-forgalmi adatokat kiterjedt háztartásfelvételre alapozott analitikus-szintetikus eljárással generálták. A tehergépkocsi-forgalom feltárására a KSH reprezentatív áruszállítási kikérdezésének többéves adatait használták fel. S noha nem az OCF projekt részeként, de gyakorlatilag ezzel egy időben, ugyanabban a szakmai mühelyben elkészült a helyközi közforgalmú közlekedés első országos célforgalmi adatfelvétele és mátrixa.

A 2008 őszén kirobbant és Magyarországot 2009-ben elért gazdasági és pénzügyi válságot követően a hazai gazdaság a 2010-es évek közepére állt talpra. Ekkor látta időszerünek a felelős minisztérium a célforgalmi mátrixok megújítását, amit az eltelt 8 év mellett a válság idején bekövetkezett, a közlekedésre is meghatározó hatást gyakorló változások is indokolttá tettek. A cikk ezt a munkát mutatja be összességében és összefüggéseiben, rámutatva azokra a pontokra, ahol jelentős innováció történt, $s$ bemutatva a legfontosabb eredményeket. Ezt teszik teljessé a jelen lapszám további cikkei, amelyek a legfontosabb munkák részleteibe avatják be az olvasót, nem elkendőzve a nehézségeket, az esetleges zsákutcákat. Meggyőződésünk ugyanis, hogy a projekt legfontosabb és távlatosan felhasznált eredményeinek, a mátrixoknak a hitelességét és megbízhatóságát létrehozásuk módszere biztosítja. A most közreadott cikkekkel ezek megismerésére kívánunk lehetőséget teremteni.

A lap terjedelme nem teszi lehetővé, hogy minden részterületet külön cikk mutasson be, így vannak olyan elemek, amelyeket csak ez a cikk tárgyal. Mindezzel arra törekedtünk, hogy az összkép teljes legyen.

\section{A feladat és lebonyolítása}

Az előzmények és a tapasztalatok ismeretében a megbízó Nemzeti Fejlesztési Minisztérium (NFM) a korábbi feladatokat jelentősen kibővítve úgy döntött, hogy a közúti mátrixok mellett - most már azokkal egy projekt keretében - ismételten készüljön közforgalmú közlekedési mátrix is. Minthogy ebben a vasút is érintett, logikus lépés, hogy a vasút egésze ( $a z a z$ az áruszállítás is) szerepeljen a projektben, valamint a teljesség érdekében a munka terjedjen ki a hajózásra és a légi közlekedésre egyaránt. Tekintettel arra, hogy a célforgalmi mátrixokkal megalapozott tervezési feladatok része az előretekintés, igényként merült fel a mátrixok előrebecslése két távlati időpontra. A projekt a TEN-T hálózatokra vonatkozó forgalmi elemzések kívánalmával lett teljes.

Az NFM pályázatot nyújtott be a projekt EU finanszírozása érdekében, ami támogatást nyert. A munka elvégzésével az NFM a KTI-t bízta meg. A korábbiaknál sokkal összetettebb feladatot mind a rendelkezésre álló időt, mind a forrásokat tekintve szorosabb feltételek mellett kellett megoldani. 
Ehhez hozzájárult az is, hogy az adatgyüjtések volumene megkövetelte a projekten belül a nyílt közbeszerzési eljárások lefolytatását. Mindez tovább erősítette azt a törekvést, - amelynek igénye a támogatási szerződésben is megfogalmazódott -, hogy a hozzáférhető legkorszerübb adatállományok felhasználásával, hatékony, innovatív módszertan kidolgozásával érjük el a kitüzött célokat.

A rendelkezésre álló idő minél jobb kihasználása érdekében a munkát 2016 tavaszán megkezdtük annak ellenére, hogy akkor még nem állt rendelkezésünkre a szerződés. Ez egyúttal a finanszírozás hiányát is jelentette, ami meggátolta a közbeszerzések elindítását. Ennek megfelelően a módszertan minél részletesebb kimunkálására törekedtünk annak érdekében, hogy az adminisztratív akadályok elhárulását követően már a munka lebonyolítására tudjunk összpontosítani. Noha az új eljárásokat célszerű kisebb feladatrészen, „pilot projekt” keretében ellenőrizni az esetleges hibák feltárása és kiküszöbölése érdekében, a finanszírozás késlekedése miatt erre csak egy esetben volt lehetőség. Ebben az autóbuszok fedélzeti eszközein készített jegystatisztika létrehozásának, feldolgozásának és kiértékelésének rendszerét vizsgáltuk. Az eredmények segítették a felkészülést a későbbi, országos adatfelvételre, de tudatában voltunk annak is, hogy még sok nehézséggel találkozunk, aminek valószínüségét növelte a fedélzeti eszközállomány heterogenitása.

$\mathrm{Az}$ eredeti tervek szerint a háztartásfelvétel megelözte volna a többi adatfelvételt annak érdekében, hogy annak a tapasztalatai és részeredményei beépülhessenek az utóbbiak eljárásaiba. Erre azonban nem volt mód, ami elörevetítette, hogy későbbi munkafázisokban fogunk több nehézséggel szembesülni.

Kedvezőbb volt a helyzet azoknál a munkarészeknél, ahol nem volt szükség nagyobb léptékű adatfelvételre, így az adatbeszerzések, illetve az erre irányuló egyeztetések már tavasszal megkezdődhettek. Ahol az adatszolgáltató állami szervezet volt, vagy a beszerzés költség igénye nem volt jelentős, ott esetenként hozzá is jutottunk az adatokhoz, s megkezdhettük az adott feladatrész kidolgozását, a korábban létrehozott eljárások alkalmazását. Ebbe a körbe tartoztak a hajózási és légi közlekedési adatok, de a vasúti áruszállítási adatok egy része is, valamint a forgalmi modell létrehozásához szükséges információk zöme.

Az adminisztratív akadályok elhárultát követően 2016 őszén lebonyolódtak az adatfelvételek, s megkezdődött az előzetesen kidolgozott módszertanok alkalmazása, a mátrixok generálása. Ahogy később látni fogjuk, az eljárások alágazatonként eltérőek, így eltérőek voltak a felmerülő nehézségek és elhárításuk módja is. Nem egy esetben vissza kellett lépni és a módszertant kellett felülvizsgálni és módosítani annak érdekében, hogy a feladat megoldható legyen. Ezek a módosítások sokszor jelentősen növelték az eljárások hatékonyságát és újszerűségét. Például a nagytehergépkocsi-mátrix létrehozásának módszertana teljes megújulást hozott, ami lényegesen meghaladta amúgy sem csekély várakozásunkat.

Komoly kihívást jelentett az elkészült mátrixok elörebecslése a két távlati időpontra, 2020-ra és 2030-ra. A KSH adatokon túl használt, különböző mühelyek által készített, a közlekedésre hatást gyakorló demográfiai, gazdasági stb. fejlődési előrejelzések eltérő területi struktúrára vonatkoznak, így egységes rendszerbe foglalásuk komoly nehézségekkel járt. Az eljárás meghatározó jelentőségű a távlati forgalmak meghatározásában, így elengedhetetlen, hogy megbízhatósága megfelelő legyen.

A több szálon futó, önálló mátrixokat létrehozó munka a TEN-T hálózaton lebonyolódó forgalom vizsgálata során fonódik össze. Ebben a munkarészben értelemszerüen nem csak alágazatonkénti elemzést végeztünk, hanem kitértünk a több alágazatot magukba foglaló folyosók forgalmi helyzetére is. Ezeket a kapcsolódásokat mutatja be az 1 . ábra, amelyen a projekt összetettségét próbáljuk érzékeltetni.

A munka egészét az NFM Közlekedési Infrastruktúrafejlesztési Főosztály felügyelte, és egy nyolc szakértőből álló tanácsadó testület támogatta, akik a jelentősebb lépések esetén a számukra eljuttatott dokumentumok alapján fejthették ki véleményüket, amelyeket a munka folytatásánál figyelembe vettünk. Emellett konzultációt folytattunk az NFM egyes szakterületeken illetékes föosztályaival is, mielőtt az egyes munkarészeket véglegesítettük. 
1. ábra: A projekt kidolgozásának egyszerüsített sémája a "jelen" idöpontra

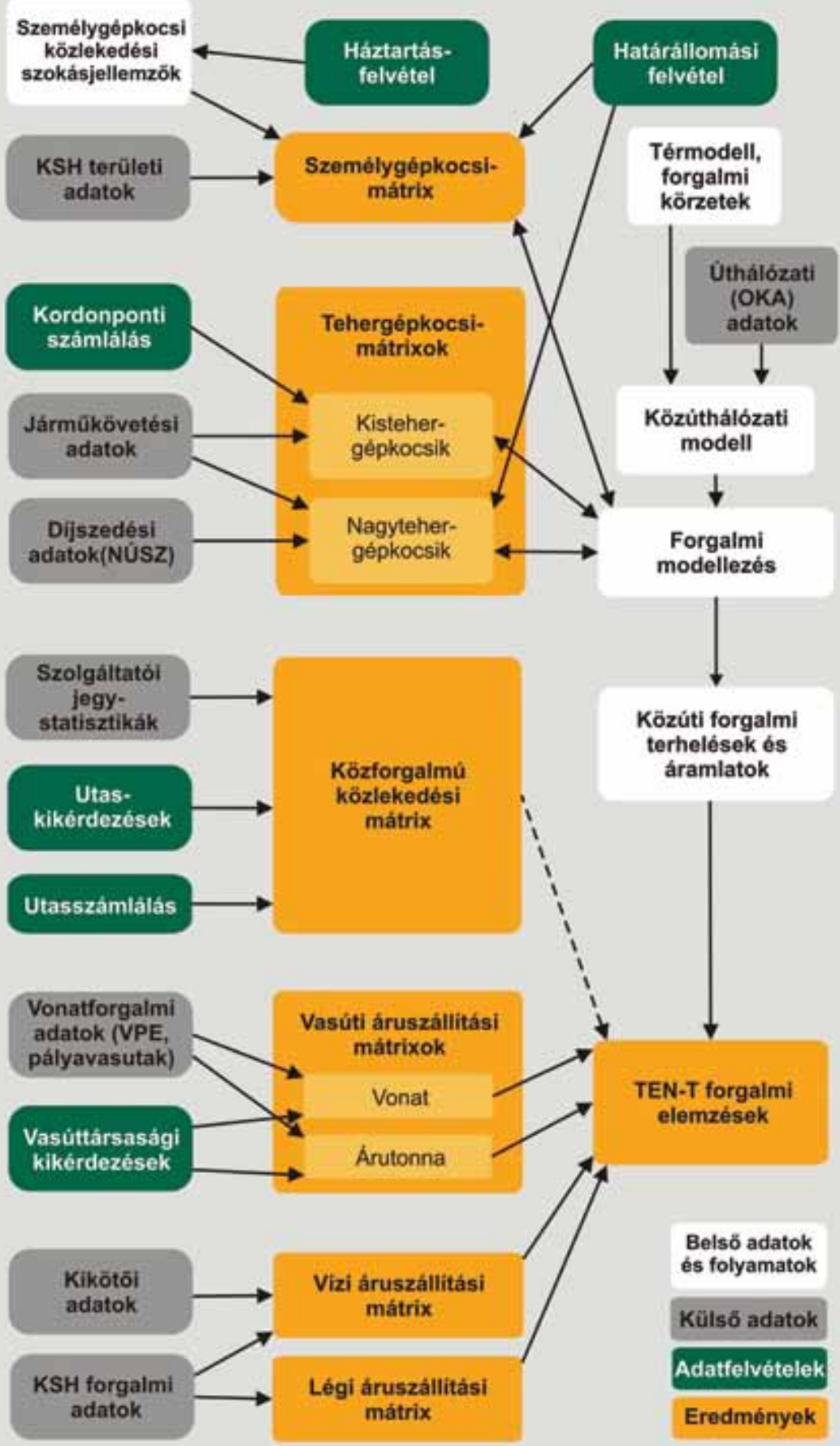




\section{MÓDSZERTAN ÉS EREDMÉNYEK}

Mint azt korábban említettem, a munka eredményét jelentő mátrixok között is van több olyan, amely elsőként a most bemutatott projektben készült, de még ezek esetében is elmondható, hogy az igazi, szinte mindegyik szakterületnél megjelenő újdonságot a módszertanok jelentik. A jelen cikkben ezeket mutatjuk be vázlatosan a kapcsolódó eredményekkel együtt. A részletekre csak ott térünk ki, ahol ezt nem teszi meg a projekt eredményeit e különszámban bemutató további hat cikk valamelyike. Erre az adott helyen felhívjuk a figyelmet.

A munka egyik első lépése annak eldöntése volt, hogy az adatgyüjtések és -beszerzések, valamint az elörebecslések és -számítások melyik évre vonatkozzanak. A mátrixok - a tervezés igényeinek megfelelően - az őszi-tavaszi hétköznapok munkába és iskolába járást is tartalmazó forgalmi igényeit mutatják be. A munka megkezdésekor csak az elöző év (2015) adatai álltak rendelkezésre, így a hozzáférhető adatokat azok kezelöitől erre az időszakra, pontosabban a 2015. október-novemberi két hónapra szereztük be. A felméréseket szintén erre a két hónapra ütemeztük, igaz, egy évvel később, 2016-ban. A két távlati időpontként a megbízóval egyeztetve 2020 -at és 2030 -at jelölték ki. Az előbbi esetében nagy biztonsággal látható elöre a fejlesztések köre, részben azért, mert ez a jelenleg folyamatban levő európai uniós finanszírozási ciklus záró éve. Ez azt jelenti, hogy az eldöntött (például infrastruktúra-)fejlesztések megvalósulása biztosra vehető, minthogy ismert azok előkészítettsége, finanszírozási háttere, továbbá ebben az időtávban mind a gazdasági, mind a társadalmi folyamatok elörejelzése jól megalapozott. Mindez összességében azt jelenti, hogy a 2020-ra készített prognózis mind a mátrixokat illetően, mind a forgalmi igényeket kielégítő infrastruktúra tekintetében nagy megbízhatóságú, ami értelemszerüen az ebböl levont következtetésekről is elmondható.

A távolabbi időpont, 2030 esetében még megfelelő megbízhatóságú demográfiai és gazdasági elörejelzések állnak rendelkezésre a köz- lekedési igények prognózisához. A tervezett - elsősorban közúti és vasúti - fejlesztések köre is rendelkezésre áll, noha megvalósulásuk megbízhatósága már alacsonyabb. A számításokat egy realista változatra végeztük el. $\mathrm{Az}$ időpontok kiválasztásánál szempont volt az is, hogy megfeleljenek a Nemzeti Közlekedési Infrastruktúra-fejlesztési Stratégia [4] első két időtávjának, biztosítva az ott elvégzett vizsgálatok frissítésének lehetőségét.

\subsection{Közúti jármüforgalom}

A legrégebbi tradíciókra a járművek mozgását egységnek tekintő közúti közlekedési adatfelvételek tekintenek vissza, $s$ a jelen munkának is ez a legösszetettebb szegmense. Ez az egyik terület, ahol számos újdonságról, s ezzel együtt több új nehézségről tudunk beszámolni.

Ahhoz, hogy a mátrixok építése, a célzott adatfeldolgozás elkezdődhessen, meg kell alkotni azt a területi modellt, amely meghatározza, hogy mely területi egységek lesznek azok, amelyek közötti forgalmat a mátrixok majd leírják. Mint a célforgalmi mátrixok történetében eddig mindig, most is az a döntés született, hogy növeljük a modell részletezettségét, ami több esetben ad majd lehetőséget az országos modell közvetlen alkalmazására regionális feladatok elvégzésére, egyúttal csökkenti a körzeten belül maradó, azaz a modellben nem megjelenő helyközi járműmozgások arányát. Ez együtt jár a belföldi forgalmi körzetek számának növelésével, ami lehetőséget ad speciális forgalomvonzó térségek elkülönített megjelenítésére. A külföldi körzetek változatlanok maradtak, azonosan a 2008-as területi modellel. A kiterjesztés szempontjai és részletei megtalálhatóak Miksztai Péter, Virág Álmos és Bozó András A hazai közúti közlekedési hálózatot terhelö forgalom elemzése c. cikkében.

A személygépkocsi-forgalmi mátrix belföldi almátrixának előállítása során sok tekintetben a 2008-ban (az OCF projekt keretében) kidolgozott analitikus-szintetikus eljárást követtük. Sem a források, sem a rendelkezésre álló idő nem tették lehetővé az akkorihoz hasonló kiterjedésű adatfelvétel lebonyolítását. Ennek következtében a szá- 
mítások részben a 2008-as utazási szokások egy szűkebb háztartásfelvételre alapozott frissítésére támaszkodtak. Ezt egészítették ki a KSH demográfiai és területszerkezeti adatai, valamint a járások fejlettségi rangsora, amelyet szintén a KSH dolgozott ki. Ennek részleteiről számol be dr. Siska Miklós és Szücs Hajnalka cikke A közlekedési szokásjellemzők alakulása, hatásuk a személygépkocsi-forgalomra címmel.

A határt átlépő személygépkocsik felmérése a korábban alkalmazott határállomási kikérdezés útján csak a schengeni külső határokon volt megoldható, ott sem teljes körüen. A schengeni belső határokon a járművek megállítására okmányellenőrzés hiányában nincsen mód, itt más megoldást kellett találnunk. Az osztrák határszakasz esetében az M1 autópályán közlekedő személygépkocsik kikérdezését a határállomás előtti utolsó üzemanyag-töltőállomásnál tudtuk elvégezni. Az osztrák relációban a mintavételi arányt csökkentette, hogy ezen a ponton még áthalad a Szlovákiába Rajkán keresztül tartó forgalom is.A többi határátkelö esetében a választ az EMAH projekt keretében korábban lebonyolított adatfelvételek adták meg. ${ }^{2}$ A többi (szlovák, szlovén, horvát, szerb és ukrán) határszakasz forgalmi adatait a KÖZOP-hoz illeszkedő projektek határmetszési szakaszainak korábbi, megvalósíthatósági tanulmány szintű feltárása biztosította.

A tehergépkocsi-mátrixok terén hajtottuk végre a legnagyobb változtatásokat. Ennek egyik tovagyűrűző hatású eleme, hogy a korábbi gyakorlattól eltérően úgy döntöttünk, hogy a személygépkocsi-forgalomról leválasztjuk a 3,5 t megengedett össztömeget meg nem haladó tehergépkocsik forgalmát, létrehozva az eddigiekben nem létező kistehergépkocsi-mátrixot. Ennek indokoltságát alátámasztja gyorsan növekvő részesedésük a jármüállományon belül, valamint az, hogy közlekedésük jellege egyértelmüen közelebb áll a többi tehergépkocsi-kategóriánál megfigyelthez, mint a személygépkocsikéhoz. A külföldi szakirodalom tanulmányozása rámutatott, hogy ez a jelenség máshol is foglalkoztatja a szakembereket, ugyanakkor az úttörőnek mondható elörelépés ebben a projektben történt meg. A módszer kialakításáról, a felmerült és leküzdött buktatókról részletesen olvashatnak Szele András A leggyorsabban fejlődő járműkategória, a kistehergépkocsik mátrixa c. cikkében.

Ahogy utaltam rá, ez a döntés túlmutat a kistehergépkocsikkal kapcsolatos eredményeken. Egyértelmübbé váltak a személygépkocsikra vonatkozó összefüggések is, ami ugyanakkor megnehezíti az összevetést a korábbi - a két jármüosztályt együtt kezelő - eredményekkel. Ha ez az elkülönítés sikeresnek bizonyul és szakmailag elfogadottá válik - amit jó okunk van feltételezni -, akkor számos helyen kell majd beavatkozni. Mint alább erre rátérünk, ide tartozik többek között néhány tervezési útmutató is.

A projektben új alapokra helyeztük a nagytehergépkocsik, azaz a 3,5 t megengedett össztömeget meghaladó tehergépkocsik és szerelvények mátrixainak létrehozását. A Nemzeti Útdíjfizetési Szolgáltató (NÚSZ) Zrt.-től kapott, a hazai díjfizetős szakaszok teljes jármüforgalmát tartalmazó adatállomány összevezetése a bevallási közreműködőktől beszerzett - díffizető tehergépkocsik 46\%-ának jármükövetési adatállományával előre nem sejtett új távlatokat nyitott. Ahogy Pusztai Ádám és Kiss István Módszertani áttörés - a nagytehergépkocsi-mátrixok kidolgozása c. cikke is érzékelteti, a hatalmas adattömeg feldolgozása során, az eljárást több lépcsőben fejlesztve jutottunk el oda, hogy olyan eszköz áll a rendelkezésünkre, amely a későbbiekben is jól használható hasonló, újabb mátrix építéséhez, illetve lehetőséget teremtett magának az eljárásnak a validálására, illetve a területi modell ellenőrzésére és továbbfejlesztésére.

${ }^{2}$ Sajátos helyzet, hogy ott el lehetett végezni a megállitásos kikérdezést a határ osztrák oldalán! A burgenlandi kollégák örömmel fogadták az általuk eddig nem alkalmazott és kedvezö tapasztalatokat hozó eljárást. Célszerü volna minisztériumi szinten kezdeményezni a szabályozás módosítását úgy, hogy a megállitásos kikérdezések újra lehetövé váljanak. 
Noha a jármükövetési pozícióadatok sok esetben mutatták a külföldi célpontokat is, az országhatárt átlépő forgalom nagyságának és fó irányainak meghatározásához továbbra is szükség volt a hagyományos kordonponti kikérdezésre. Ennek során ugyanazok a nehézségek merültek fel, mint a személygépkocsik esetében, illetve meg kellett oldani a kétféle forrásból származó, de részben redundáns állományok egyesítésének problémáját is.

A leírt módon létrehozott „nyers” közúti közlekedési mátrixok finomítását tette lehetővé a számítógépes forgalmi modellezés, amelynek részleteiről szintén a korábban említett Miksztai-Bozó-Virág szerzők cikke számol be.

\subsection{Közforgalmú közlekedési utasforga- lom}

A közforgalmú közlekedési mátrix egysége az utas, és területi modellje is eltér a közúti közlekedésétől, itt ugyanis egy utazás kiindulási és célpontja megállószinten azonosítható. Helyközi utazások esetében általában elegendő a település megadása, amit az is indokol, hogy az utazás jellemzően nem a felszállási megállóban kezdődik, nagyobb településeken az odajutás jelentősebb távolságról is történhet, akár másik jármü, pl. kerékpár igénybevételével. Ezért döntöttünk úgy, hogy településközi mátrixot hozunk létre.

A mátrixok generálásának alapadatát a korábban regionális léptékben már hasonló célra felhasznált szolgáltatói jegystatisztikák jelentették. Ez a MÁV-START-nál az utóbbi évek fejlesztésének köszönhetően az eladásokat illetően már folyamatosan keletkezik, s a jegyértékesítési (JÉ) projekt kiteljesedését követően a felhasználásról is nagyon részletes kép áll majd rendelkezésre. Az autóbuszos szolgáltatók esetében egynapos célirányos adatgyüjtésre került sor, amihez az egyes szolgáltatóknál különböző mértékű fejlesztésre volt szükség, hogy a fedélzeti jegykiadó berendezések erre alkalmasak legyenek. A nehézséget a különleges esetek kezelése (pl. nem elsőajtós felszállás a buszon), a vasúton díjmentesen utazók regisztrálása, valamint az átszállások nyomon követése jelentette. Mindezek megoldására a fontosabb átszállóhelyeken és a vasúti járműveken célforgalmi kikérdezést, s ahol szükséges volt, ott hagyományos utasszámlálást végeztünk. Tekintettel arra, hogy így az adatfelvétel majdnem minden elemében eltért a korábbiaktól, a mátrixgenerálás módszertanát is gyökeresen meg kellett újítani. Ezt mutatja be részleteiben az autóbusz-közlekedésre összpontosítva Munkácsy András és Vass Lajos Utasforgalmi vizsgálatok a helyközi autóbusz-közlekedésben c. cikke.

\subsection{Vasúti forgalom}

A vasúti hálózat kevésbé szerteágazó, mint a közúti, a benne rejlö kötöttségek, a szigorú szabályozás és a vasútüzem sajátosságai következtében mégis nagyon sok buktatóval kellett megküzdeni a mátrixok létrehozása során. Külön nehézséget jelentett, hogy a piac diverzifikációja következtében nehezen lehetett megismerni a jelentős részarányt képviselő határt átlépő teherforgalom külföldi végpontjait. Minthogy ez a szállítási forma mutat némi hasonlóságot a közúti szállítással (bizonyos szállítási távolságokon versenytársai is egymásnak), a területi modell megegyezik a közúti mátrixoknál alkalmazottal, azaz a forgalmi körzetek korábban bemutatott rendszerével.

A vasútüzem sajátosságainak megfelelően az áruszállítást illetően két mátrix készült, az egyik az áruk, a másik a vonatok áramlását írja le. Ez utóbbi a közúti forgalomhoz hasonlóan jármüalapon közelíti meg a forgalom egyes kérdéseit, például a pályakapacitás kihasználását. Itt azonban egy „jármü”, azaz vonat befogadóképessége nagyon széles skálán mozog, ezért volt szükség a szállított javak valamilyen egysége, célszerüen a tömege szerinti célforgalmi mátrix kialakítására is. A módszertan részleteit és a fontosabb eredményeket dr. Berényi János és Oszter Vilmos Célforgalmi vizsgálatok a magyar vasúti hálózaton c. cikke mutatja be, kitérve a közforgalmú közlekedés korábbiakban tárgyalt vasúti vonatkozásaira is. 


\subsection{Vízi áruszállítás}

A vízi közlekedés esetében kizárólag az áruszállítással foglalkoztunk, minthogy a vízi személyszállítás elsősorban üdülőforgalmi jellegü, így csúcsidőszakában is eltér a többi alágazat mértékadó személyforgalmától. Ennek következtében a vizsgálat a Dunával foglalkozik, amelynek $417 \mathrm{~km}$ hosszú magyarországi szakaszán 56 terminál végez kikötői (árurakodói) tevékenységet. A területi modell igazodik a vízi út kötöttségeihez, azaz a kikötők vagy azok (NUTS2) régiói képezik az alapegységet. Az áruszállítás teljesítményének adatait a KSH, valamint a Duna Bizottság Statisztikai Adatlapjai biztosították, amelyek szintén a KSH adatain alapulnak.

A hazai áruszállítás jellegzetessége, hogy árutonnakm-ben mért teljesítményének döntö része határt átlépő $(99,4 \%)$, ezen belül is jelentős a tranzit $(51,6 \%)$. A magyarországi végponttal szállított áruk többsége a Mezőgazdasági, vadászati és erdészeti termék kategóriába sorolható volt 2015-ben (37,8\%). Ezt követően a Fémtartalmú ércek és egyéb bányászati és kőfejtési termékek (elsősorban vasérc, homok, kavics) következtek 15,7\%-ban, valamint Koksz és finomított kőolajtermékek 14,3\%ban.

$\mathrm{Az}$ átrakott árumennyiség tekintetében a három legfontosabb dunai kikötő Izmail (Ukrajna), Linz (Ausztria) és Galac (Románia), míg Magyarországon Budapest és Dunaújváros.

2015-ben a Magyarországon áthaladó nemzetközi szállításokban a legnagyobb forgalommal rendelkező relációk az alábbiak voltak:
A tételes kikötői forgalmakat vizsgálva pontosan kirajzolódnak az export- és importforgalom legjelentősebb kikötői. Export tekintetében Baja, Budapest és Paks forgalma a legjelentősebb, míg a hazánkból induló szállítmányokból a legnagyobb mennyiséget Konstanca, a Bécs és Krems között fekvő Pischelsdorf, valamint a szerbiai Szendrö fogadja. Import tekintetében Dunaújváros és Budapest kikötője adja a forgalom $84 \%$-át. (A módszertan és az eredmények részletei a projekt dokumentációjában találhatók meg.)

\subsection{Légi fuvarozás}

A magyarországi hat ICAO kóddal rendelkező repülötér közül egyedül a budapesti Liszt Ferenc Nemzetközi Repülötér forgalma számottevő. Az ország közlekedése szempontjából ez a hálózat egy csomópontja, amely kibocsátó, illetve fogadó pontja más közlekedési módokon érkező/távozó utasoknak és áruknak. 2015-ben a KSH által megfigyelt összesen 11,8 millió utasból 11,4 millió ebben a légikikötőben fordult meg.

A Budapeströl induló utasok 84\%-a valamelyik európai repülötérre tart, s az érkező utasok is onnan érkeznek. A legtöbben Nagy-Britanniába repülnek, 2008-ban még a most második Németország vezette a listát. Kiemelkedő még a Belgiumba, Franciaországba, Hollandiába, Olaszországba, Spanyolországba, Svájcba, Svédországba és Törökországba utazók száma is. Az utasforgalmat hazánk esetében is - a nemzetközi trendeknek megfelelően - a munkavégzéssel és a szabadidő eltöltésével kapcsolatos utazások generálják. Az érkező utasok 72\%-a is az előzőekben felsorolt tíz országból repül Budapestre.

1. táblázat: A legnagyobb forgalommal rendelkező vízi szállítási régióközi relációk (Forrás: KSH)

\begin{tabular}{|c|c|c|c|}
\hline Honnan (berakási régió) & Hova (kirakási régió) & Tonna & Tonnakm \\
\hline Ukrajna (UAZZ) & Felső-Ausztria (AT31) & 814278 & 308611362 \\
\hline Felső-Ausztria (AT31) & Szerbia (RSZZ) & 124185 & 47066115 \\
\hline Felsö-Ausztria (AT31) & Dél-Románia (RO31) & 118146 & 44777334 \\
\hline Délkelet-Románia (RO22) & Alsó-Ausztria (AT12) & 113684 & 43086236 \\
\hline Felső-Ausztria (AT31) & Délkelet-Románia (RO22) & 82830 & 31392570 \\
\hline
\end{tabular}


A repülőtér szerepe a légi áruszállításban még inkább egyeduralkodó, az összes mennyiség 99,8\%-a köthető Ferihegyhez Az utóbbi években a budapesti légikikötőben évente $62-77$ ezer tonna áru fordult meg. Ezt az árumennyiséget teljes egészében közúton kellett mozgatni, mivel a repülötérnek nincs áruszállításra alkalmas vasúti összeköttetése. A kerozinellátást ugyanakkor közvetlenül csővezetéken oldották meg a MOL Dunai Finomítójából.

Az áruforgalomban valamivel nagyobb az érkező áruk tömege, mint a Budapestről indulóké. 2016-ban 77 ezer tonna küldemény indult és érkezett Budapestre. A küldő és fogadó országok listáját magasan Németország, azon belül is Lipcse vezeti. Itt található ugyanis a DHL európai elosztó központja. Fontosak még a belgiumi, franciaországi, hollandiai és törökországi repülőterek is. Az utasforgalommal ellentétben az áruforgalomban nem elhanyagolhatók a Romániába és Szerbiába irányuló, illetve onnan származó szállítmányok sem. Figyelemre méltó, hogy a beérkező légi fuvarok mennyiségének közel negyede Kínából származik. (A módszertan és az eredmények részletei a projekt dokumentációjában találhatók meg.)

\subsection{A távlati forgalmi mátrixok létrehozása}

Ahogy a feladatleírásnál már megemlítettük, a megbízók részéről határozott igény volt két távlati időpontra - a döntés szerint 2020-ra és 2030-ra - a mátrixok előrebecslése.

Ismeretes, hogy a közlekedés átszövi a társadalmi és gazdasági folyamatokat, kihat azok alakulására, illetve azok is visszahatnak a közlekedés fejlődésére. Ezért a közlekedési gerinchálózattal szemben várhatóan jelentkező igények elörebecslésére kidolgozott eljárásban a következő főbb folyamatok jövőbeni tendenciáit vettük figyelembe:

- a demográfiai jellemzők (népesség nagysága, korstruktúrája, belföldi és nemzetközi migráció hatása),

- az oktatás-képzés alakulása,

- a településszerkezet változásai,

- a gazdaság egésze teljesítményének alakulása,

- a gazdaság szerkezetének átalakulása,
- a népesség gazdasági aktivitása,

- a közlekedés terén bekövetkező technikai, technológiai változások hatásai,

- s végül, de egyáltalán nem utolsósorban a közlekedők szokásainak változásai (módválasztási preferenciák, utazási hajlandóság stb.).

A szempontok jelentős része nem a közlekedési szakterület része, ezért kerestünk olyan forrásokat, amelyek megfelelö részletességgel foglalkoznak a fenti kérdésekkel. Magyarország hosszú távon várható társadalmi-gazdasági fejlődésére vonatkozó egyik legfrissebb kutatást az MTA KRTK publikálta [5]. A kutatás kitér a legfontosabb demográfiai folyamatok, valamint a gazdaság egészének várható alakulására a 2051-ig terjedő időszakban. Számunkra a projekt különösen értékes amiatt, hogy a tudományos igényességgel készült előrejelzések járási/ megyei szinten is elérhetők a NATéR (Nemzeti Alkalmazkodási Térinformatikai Rendszer) adatbázisán keresztül. Azokon a területeken, ahol ez a munka nem adott támpontot, saját kutatást végeztünk. Ide tartozik például az oktatás, $s$ részben a szokásjellemzők változása.

A mátrixok előrebecslésénél a fenti hatások érvényesülését az adott közlekedési mód sajátosságai szerint differenciáltuk. Míg a személygépkocsi-forgalom esetében a megyei szintű GDP változást és a munkaképes korú lakosság számának települési szintű alakulását, addig a tehergépkocsi-forgalomnál a forgalmi körzetek GDP változása által mozgatott szállítási igényváltozást és a szállítási piac átrendeződése miatt a jármükategóriák között létrejövő átrendeződést vettük figyelembe. Ez azt jelenti, hogy - némi egyszerüsítéssel - nem a mátrixokra, hanem azok egyes elemeire, elemcsoportjaira generáltuk a távlati fejlődési szorzót.

\subsection{A TEN-T hálózat forgalmi elemzése}

A TEN-T hálózat forgalmi elemzését két szinten végeztük el. Egyrészt alágazatonként, esetleg járműosztályonként, ahol elsősorban az egyes hálózati elemek funkcionális szerepét domborítottuk ki, hogy milyen relációk forgalmának lebonyolításában játszanak kulcsszerepet. Itt vizsgáltuk a nagyobb határátkelőket, valamint a fontosabb artériák távolsági forgalom szempontjából mértékadó 
keresztmetszeteit. Másrészt vizsgáltuk a forgalom lebonyolódási viszonyait, ami alapvetően a pálya kapacitásának kihasználtságával függ össze, így itt a különböző forgalmi rétegek együttes hatását elemeztük az adott pálya, illetve a több pályát is magában foglaló TEN-T folyosó vonatkozásában.

A légi és a vízi közlekedés esetében egyértelmü volt a helyzet, mivel a vizsgált hálózat megegyezik a TEN-T hálózattal, így az általános megállapítások arra is vonatkoznak. Ez már nem teljesül a vasúti forgalom esetében sem, de különösen nem a közúti forgalomnál. Ez utóbbinál az elemzést segítette a forgalmi modell, lehetőséget adva mind a kapacitás, mind a funkcionális vizsgálatokra. Ezek részletei is megtalálhatók a már többször említett Miksztai-Virág-Bozó szerzők cikkében.

Az elkészült TEN-T elemzések számos megállapítást tartalmaznak, ezek taglalása meghaladná a jelen cikk terjedelmi korlátait. Csak néhány - inkább megerősítő, semmint meglepő - megállapítást idézünk:

- A személygépkocsi-forgalom esetében a legforgalmasabb relációk egyik végpontja $\mathrm{Bu}-$ dapest. Ezen kívül még a legnagyobb vidéki városok közötti forgalom éri el a napi 1000 jármű mennyiséget. Ezeknek a relációknak egy része a TEN-T törzshálózatot, illetve a budapesti körgyürüt veszi igénybe.

- A TEN-T közúti törzshálózat magyarországi szakaszai közül az M1-M5 autópályák kapacitása majdnem teljes hosszban viszonylag egyenletesen kihasznált már ma is. Ennek a forgalomnak jelentős része nemzetközi relációban közlekedik, például a Csanádpalotánál belépő személygépkocsik 40\%-a elhagyja hazánkat Hegyeshalomnál és Tornyiszentmiklósnál.

- A hegyeshalmi átkelők utazásának kétharmada végződik Burgenlandban vagy Bécsben.

- A kistehergépkocsik kevésbé érzékenyek az útdíjra, így ahol lehet, a gyorsforgalmi hálózatot használják a párhuzamos foúthálózattal szemben.

- Az átfogó hálózat egyik legterheltebb eleme az M86-os autóut, amelyen 2200 nagytehergépkocsi fordul meg naponta. Itt a tranzitforgalom - Ausztriát elkerülve - a Rajka-Rédics útvonalon Lengyelország, Csehország, Szlovákia és Szlovénia, Olaszország kö- zött áramlik.

- A vasúti áruszállítás mintegy 85\%-ban halad a hazai TEN-T törzs- és átfogó hálózat valamely szakaszán.

- Az árutonnában mért vasúti áruforgalom 71\%-a tekinthető nemzetközi szállításnak, ami lényegesen magasabb érték a közúti alágazathoz képest (21\%, KSH, 2016). A helyzetet jól jellemzi, hogy ennek a forgalomnak 77\%-a uniós országok felé irányult.

- A magyarországi repülőterekre a következő tíz évben várhatóan évente átlagosan 5,3\%-kal, a rákövetkező évtizedben pedig még mindig évi átlagosan 4,1\%-kal több utas fog érkezni, tehát 2020-ban mintegy 14 millió utasra, 2030-ban pedig már akár 22 millió utasra számíthatunk.

\subsection{Egyéb eredmények}

A kitűzött feladat értelmében két, egymással szoros összefüggésben álló útmutatót kellett megvizsgálnunk, hogy a projekt eredményei alapján frissítésre szorul-e egy vagy több elemük.

Az „Ưtmutató az országos közúthálózat új külterületi szakaszainak és új forgalomvonzó létesítménnyel érintett útjainak forgalmi elörebecsléséhez" (GKM, 2003) esetében megállapítható, hogy módszertanilag nem szorul frissítésre, ugyanakkor a gyorsan változó adatforrás-megjelöléseket célszerű volna elhagyni. Felülvizsgálatra szorulnak a távlati forgalom egyszerüsített meghatározását szolgáló forgalomfejlődési szorzók, helyettük a jelen projekt differenciált forgalomfejlődési tényezőit javasoljuk alkalmazni.

A „Módszertani útmutató egyes közlekedési projektek költség-haszon elemzéséhez" (TRENECON, 2016) az első közreadása óta eltelt időben számos frissítésen esett át. Ennek következtében csak akkor szorul aktualizálásra, ha elfogadottá válik a kistehergépkocsik forgalmának elkülönített kezelése. Erre ugyanis az eljárás nincs felkészítve, s egy ilyen módszertani módosítás nem csak a kistehergépkocsikra vonatkozó értékek megadását jelentené, hanem az eddig ezekkel közösen kezelt személygépkocsikra vonatkozó értékeket is felül kell vizsgálni. Erre egy célzott kutatási munka keretében nyílhatna lehetőség. 


\section{4. ÖSSZEGZÉS}

A mátrixok kidolgozása során felhasználtunk csaknem minden rendelkezésre álló adatot, információt, ami pontosíthatta, illetve megbízhatóbbá tehette a végeredményt. A kistehergépkocsik elkülönített kezelése megnehezíti ugyan az összevetést a korábbi célforgalmi eredményekkel, ugyanakkor szintén a pontosság növelésének irányába gyakorol hatást, mind a személygépkocsi, mind a tehergépkocsi mozgások meghatározása terén. A nagytehergépkocsik mátrixának új módszertana és a minta drasztikus növekedése együttesen jelentősen javította a mátrix megbízhatóságát. Minden bizonnyal növekedett a közforgalmú közlekedési mátrix megbízhatósága is, annak ellenére, hogy az adatfelvételt számos helyen sújtotta a heterogenitás.

Fontos kiemelni, hogy ezen a téren a technológiai fejlődés igen gyors, így várható, hogy a következő mátrixfrissítésnél a személyek helyváltoztatásának regisztrálására gyökeresen új, valószínűleg a mobiltelefon-mozgások megfigyelésére, valamint az integrált elektronikus jegyrendszer adataira támaszkodó módszert alkalmaznak majd.

Hangsúlyozni szeretnénk, hogy a munka során egy megújított eszköztárat hoztunk létre, amely önmagában nem ad választ a közlekedési fejlesztések kapcsán rendszeresen megfogalmazott kérdésekre. Módot ad viszont

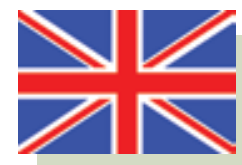

The New National Origin-Destination Matrices (OCM-2016) as the cornerstones of transport planning

In 2016-2017, the seventh generation of nationwide OD matrices was completed with the contribution of the staff of KTI Institute for Transport Sciences. During a work more complex than ever before, for the first time OD matrices were generated for all four transport sub-sectors as well as public transportation and many important innovations were made in their methodology. This was accompanied by using several, hitherto unavailable, advanced databases. The article reviews the entire project, pointing out innovative aspects and highlighting connections to articles in the special edition discussing technical details. arra, hogy ezekre az adatokra támaszkodva a szakemberek megadják a helyes választ vagy a lehetséges válaszokat a döntéshozók számára. Bízunk benne, hogy az elkészült, s itt bemutatott munka eredménye megbízhatóan szolgálja majd a következő 8-10 év közlekedési fejlesztéseihez kötődő döntésalkotást.

\section{FELHASZNÁLT IRODALOM}

[1] Szalkai Gábor (2008): A közúti forgalom változása Magyarországon (1869-2006). Doktori értekezés, Budapest

[2] Robert Emmanuel Barkley (1951): Origindestination surveys and traffic volume studies. Highway Research Board, Bibliography No.11, December 1951

[3] Albert Gábor (2010): Az országos célforgalmi mátrix (OCM 2008) kidolgozása és néhány eredménye. Közlekedésépítési Szemle 60. évf. 9. sz.: 1-6.

[4] Nemzeti Közlekedési Infrastruktúra-fejlesztési Stratégia. http://www.kormany. hu/download/b/84/10000/Nemzeti\%20K\%C3\%B6zleked\%C3\%A9si\%20 Infrastrukt\%C3\%BAra-fejleszt\%C3\%A9si\%20 Strat\%C3\%A9gia.pdf

[5] Czirfusz Márton, Hoyk Edit és Suvák Andrea (szerk., 2015): Klímaváltozás társadalom - gazdaság. Hosszú távú területi folyamatok és trendek Magyarországon. Publikon Kiadó

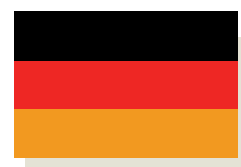

\section{Die neue Quelle-Ziel-Matrizen (OCM-2016) als Grundsteine der Transportplanung}

In den Jahren 2016-2017 wurde die siebente Generation der nationalen QZ-Matrizen unter der Mitwirkung der Mitarbeiter des Instituts für Verkehrswissenschaften erstellt. Im Rahmen dieser Arbeit, die komplexer war als je zuvor, wurden zum ersten Mal für alle vier Verkehrssektoren sowie für ÖPNV die QZ-Matrizen erstellt und es wurden eine Reihe von bedeutenden Innovationen in der Methodik der Matrixerzeugung durchgeführt. Dies brachte die Verwendung einer Reihe von zeitgemäßen Dateien mit, die bisher nicht verfügbar waren. Dieser Artikel bietet einen Überblick über das gesamte Projekt. Er verweist auf die innovativen Elemente und markiert die Anknüpfpunkte zu den anderen, die beruflichen Einzelheiten darstellenden Artikeln dieser Sonderausgabe. 